\title{
DEVELOPMENT OF CIRCULAR ECONOMY IN GERMANY: TRENDS AND PROSPECTS OF EXPERIENCE IMPLEMENTATION IN UKRAINE
}

\author{
Venherska N. S., Strelnikov P. I. \\ Zaporizhia National University, Ukraine, 69600, \\ Zaporizhzhya, Zhukovsky street, 66 \\ nataljavengerskaja@ukr.net,philipin@ukr.net \\ ORCID ID 0000-0001-8171-8206 , 0000-0001-8373-5253
}

\section{Key words:}

circular economy, German, implementation, economic model, correlation and regression analysis, closed loop, resource supply, ecology.
The article reveals the peculiarities of the development of the circular economy in Germany and the perspectives for the implementation of this economic model in Ukraine. Germany positions itself as one of the most ambitious nations in the field of eco-innovation, digitalization, environmental protection and the development of a circular economy. This country develops many patents and projects and has a sufficient number of qualified personnel. There are also strong industrial sector and high standards of safety and environmental protection. Such a meaningful German experience of implementing a new model of circular economy will be useful for Ukraine as well. Ukrainian economy, the social and political spheres need to be reformed, as they now face many problems and crises. The application of the methods and foundations of the circular economy is extremely difficult without foreign intervention and investment. Therefore, it is now necessary at least to get acquainted with and learn from the experience of more developed countries, where the implementation of the circular economy is already a priority. The article analyzes the dependence of emissions of certain substances and carbon dioxide on capital investments in environmental protection in Ukraine. There are also suggestions for solving the problems of pollution by harmful substances through the use of special technologies for capture and storage. The advantages and disadvantages of the transition to a circular economy, possible barriers and obstacles are revealed.

\section{РОЗВИТОК ЦИРКУЛЯРНОЇ ЕКОНОМІКИ В НІМЕЧЧИНІ: ТЕНДЕНЦІЇ ТА ПЕРСПЕКТИВИ ІМПЛЕМЕНТАЦІЇ ДОСВІДУ В УКРАЇНІ}

\begin{abstract}
Венгерська Н. С., Стрельніков П. І.
Запорізький наиіональний університет

Україна, 69600, м. Запоріжжя, вул. Жуковського, 66

У статті розкриваються особливості розвитку циркулярної економіки в Німеччині та перспективи імплементації цієї економічної моделі в Україні. Німеччина позиціонує себе як одна 3 найамбітніших націй у сфері екоінновацій, діджиталізації, захисту навколишнього середовища та розвитку циркулярної економіки. Ця країна розробляє багато патентів та проектів, має достатню кількість кваліфікованих кадрів, потужний промисловий сектор та високі стандарти безпеки i захисту навколишнього середовища. Такий змістовний німецький досвід імплементації нової моделі кругової економіки буде корисним і для України. Українська економіка, її соціальна та політична сфера потребують реформування, адже зараз стикаються 3 багатьма проблемами та кризами. Застосування методів та основ циркулярної економіки є вкрай важким без іноземного втручання та капіталовкладення. Тому зараз треба як мінімум знайомитись та переймати досвід більш розвинутих країн світу, де питання імплементації кругової економіки вже $\epsilon$ пріоритетними. В статті дано аналіз залежності викидів певних речовин та вуглекислого газу від капітальних інвестицій в охорону навколишнього середовища в Україні. Також надаються пропозиції щодо вирішення проблем забруднення шкідливими речовинами шляхом застосування спеціальних технологій уловлювання та зберігання. Розкрито переваги та недоліки на шляху переходу до циркулярної економіки, можливі бар'єри та перешкоди.
\end{abstract}

\section{Statement of the problem}

Germany positions itself as one of the most ambitious nations in the field of eco-innovation, digitalization, environmental protection and the development of a circular economy. This country develops many patents and projects, has a sufficient number of qualified personnel, a strong industrial sector and high standards of safety and environmental protection. However, in 
Germany there are barriers in the automotive sector, where environmental regulation and economic instruments are reluctant to work because they slow down the potential. Other obstacles to the circular economy are the excessive capacity of energy-processing facilities and too few incentives to prevent waste. Germany still does not have a special Eco- Innovation Action Plan (Eco-AP). Therefore, the issue of implementation of the circular economy in the world is becoming increasingly important and necessary.

The problems of resource depletion, the instability of the world market and the environmental situation need to be addressed immediately. Many companies are now seeking protection in the face of global market instability. Some lack innovative and resource-efficient ways of production and consumption. All these obstacles and barriers are somehow combined with the new model of the circular economy. The Ukrainian economy, its social and political spheres need to be reformed, as they now face many problems and crises. The application of the methods and foundations of the circular economy is extremely difficult without foreign intervention and investment. Therefore, it is now necessary to at least get acquainted with and learn from the experience of more developed countries, where the implementation of the circular economy is already a priority.

\section{Analysis of recent studies and publications}

Research on this topic describes the circular economy as the key to economic growth through balanced resource consumption. The importance of the circular economy for Germany in the first place is emphasized. The authors share their views on the implementation of this economic model in the world. In Germany, the essence and principles of the circular economy are studied in detail. This theme appears in the works of German authors such as R. C. Brears [1], Th. Weber, M. Stuchtey [2], M. Nelles, J. Grünes, G. Morscheck [3] and others. In addition to foreign scholars, the circular economy is studied in the works of Ukrainian authors such as J. Fedorchuk and D. Servetnyk [4]. ALBA Group also makes a significant contribution to understanding what a circular economy is. It details this concept into facts and topics, providing analytical and statistical information.

\section{Objectives of the article}

The aim of the article is to highlight the peculiarities of the development of the circular economy in Germany and to develop scientific and practical recommendations on the prospects for the implementation of the German experience in Ukraine.

\section{The main material of the research}

The development of countries and society as a whole, their production relations, use of resources and their efficiency are very relevant in today's changing world. Therefore, the introduction of new economic models entails the optimization of economic processes, recovery and rational consumption of resources. It is a closed-cycle economy or a circular economy, which is an alternative to the traditional, linear. The circular economy is an integral part of the sustainable development of the world.

One of the prerequisites for the introduction of a circular economy is the issue of ecology and conservation of natural resources. The circular economy model assumes the most efficient use of available resources by minimizing the emergence and destruction of unprocessed waste and extending the duration product operation. But most importantly, the circular economy has not only environmental efficiency but also economic. Maximum use of resources contributes to increased capital productivity, which leads to increased profits at the micro level and improved key macroeconomic indicators at the macro level. Therefore, the introduction of a circular economy in all spheres of life is appropriate. But because the concept of this model is relatively new, it is still little studied. In particular, the issues of assessing the degree of implementation and efficiency of the circular economy have not been sufficiently studied.

The linear model of the economy is now being revised in most countries of the world. In the meantime, this model is far from ideal and has a number of negative factors: air pollution and constant emissions into the air; the problem of lack of resources and their exhaustion; $\mathrm{CO} 2$ emissions into the atmosphere that lead to global losses; the areas of land plots under waste that are stored and not used are used [5].

The circular economy is characterized by energy efficiency, innovation, resource conservation and closed cycle. According to Chinese statesman Chen Demin: "The circular economy is a kind of pattern of economic exploitation, according to which material resources can be used in a circle, ie re-included in production. The purpose of the circular economy is to ensure the endless use of material resources"[6]. That is, we can conclude that with the help of a circular economy, waste becomes a source of added value. The development of the circular economy can become an integral part of the fourth industrial revolution, which is predicted in the future.

According to Eurostat and the European Parliament, Germany now outperforms other European countries in terms of sustainable development. Germany is also making progress in studying a new model of closed economy. Annual domestic consumption of raw materials in Germany is 15 tons per capita, which is twice the world average. The government has set a goal of conserving natural resources and increasing overall raw material production by $30 \%$ by 2030 compared to 2010 . One of the government's programs to achieve this goal is to use the methods of circular economy and its resource efficiency. This program includes grants for joint projects during 2019-2022. There is a need to create a new concept of production and processing, modernization of packaging in an environmentally friendly way, and so on. The general essence is to develop innovative products and technologies that reduce the negative impact on the environment and promote modernization, reuse. The initiative stimulates consortia, which mainly include small and medium enterprises, to develop and implement economically viable production cycles [1] (Fig. 1).

Germany plans to generate about $80 \%$ of its electricity from renewable sources by 2050 . Now this figure reaches 
one third of the total energy. However, wind and sun are not stable sources and this is a problem for electricity networks and operators. An interesting way to balance fluctuations in supply and demand is to store this resource. A number of technologies are already being tested and used, but they still need to be improved. Today, one of the

\section{Why - fundamental motivation for systemic change \\ Develop a concrete shared vision for the Circular economy as a means for achieving important social goals}

exits is seen in storage facilities. They are an effective way to efficiently store large amounts of energy. These units pump water into the tank at a higher level, store it there and re-release it when necessary, converting it into electricity through a generator connected to the turbine.

\section{$>$ \\ Where to - the target system \\ Develop a consistent system of targets and indicators for control and tracking. \\ Systematically prepare specific proposed \\ solutions to barriers and incentives for \\ the Circular Economy. Develop a \\ national Circular Economy roadmap \\ based on the vision and target system}

\section{How - measures for implementation}

Initiate specific measures for fostering business models and technologies. Establish "circular clusters" to focus development on fields of particular significance for the future. Initiate an educational initiative to embed the central ideas of a Circular Economy and the systemic approach in relevant curricula. Position Germany in the EU and internationally as a Circular Economy pioneer

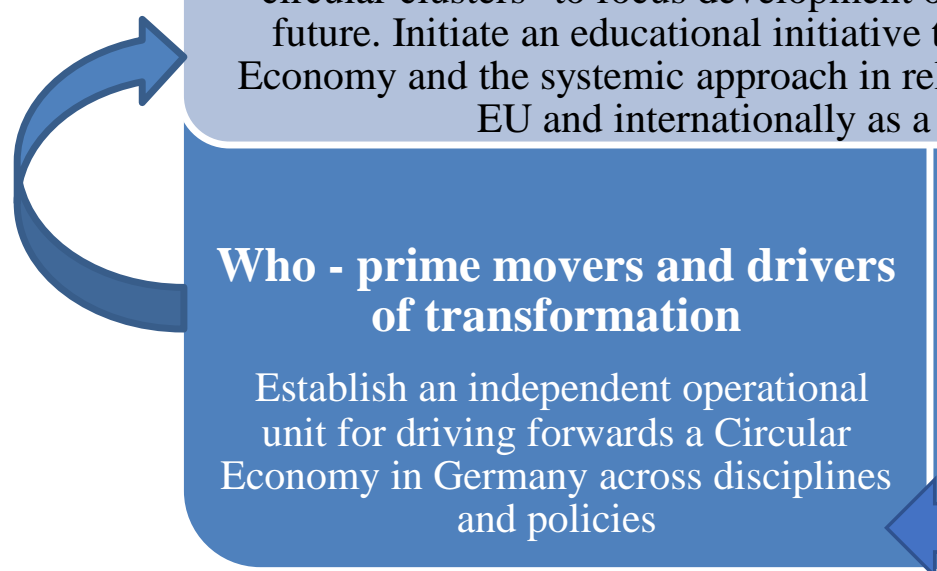

With whom - engagement of interest groups

Establish a cross-sectoral, precompetitive space in which information

is openly exchanged, partnerships are

established and (industry) standards are defined

Рис. 1 Options for shaping the transition to a Circular Economy in Germany Source: compiled by the author based on [2]

Another option in the medium term will be the storage of compressed air. This technology compresses the air into underground caves. Then the compressed air can drive the turbine to generate electricity. This, however, is only useful for storing energy for a few hours or up to a day. In addition, compressed air storage technology is limited. What is missing is long-term storage, able to overcome the longer phases of lack of wind and a small amount of sunlight. However, a solution has also been found in this case. And this is a technology in which electricity is used to produce gaseous fuel. This method converts water to hydrogen or possibly to methane. The advantage is that hydrogen and methane can be transmitted, stored and transported in and through gas networks (but with certain restrictions), as well as, if necessary, converted into electricity. The disadvantage of this technology is that it is still very expensive [2].

Using batteries is also a problem area in fact. The production of lithium batteries requires a lot of critical raw materials, and their disposal generally leaves much to be desired. An acute shortage of resources is forecast in the future. According to the International Energy Agency, in 2019 there were 2 million electric cars in the world. By 2040, their number will increase to about 40 million. Demand for cobalt and lithium is increasing. Demand for lithium is estimated to quadruple to 779,000 tons in 2025 . According to Benchmark Mineral Intelligence forecasts, demand for nickel will grow from 75,000 tons in 2016 to 400,000 tons in 2025. [7].

An equally important issue for the introduction of a circular economy is its implementation in Ukraine. This is especially true of environmental pollution, waste management, investment and the cost of optimizing and addressing these issues. For example, in the period from 2013 to 2015, Ukraine was among the twenty countries with the highest emissions of carbon dioxide. This fact, together with the difficult energy situation in the country, made it quite attractive for members of the world community willing to invest in environmental projects. Further, from 2016 to 2018 there is a noticeable trend to reduce emissions of certain pollutants and carbon dioxide.

The German non-governmental organization Germanwatch, together with its partners, presented a rating on climate change prevention during the UN conference on climate protection. Ukraine took 18th place in this ranking. Climate policy experts acknowledge that this is a fairly high place for our country. However, they also claim that this is not the result of a successful state climate policy, but the influence of certain external and internal factors [8]. 
Ukraine is experiencing an industrial and economic downturn amid a crisis, industrial decline, war in the East, and later the effects of the coronavirus pandemic. A gradual decrease in energy consumption was also revealed. However, there is also a positive effect because the amount of emissions of certain substances is reduced. For example, the dynamics of carbon dioxide emissions in Ukraine is declining (Table 1). This is a chance to improve the environmental situation, perhaps try to change the economic model, attract investment and innovation. Ukraine really needs this. Therefore, the table below shows emissions of certain pollutants and capital investment in environmental protection.

Correlation-regression analysis proved the connection between these data and the importance of investing in the environment (Table 2). The correlation coefficient is 0.77 and this figure is close to one.

Table 1 - Dynamics of emissions and investments in the field of environmental protection in Ukraine, UAH million [9]

\begin{tabular}{|c|c|c|}
\hline Years & $\begin{array}{l}\text { Emissions of some pollutants and carbon } \\
\text { dioxide }\end{array}$ & $\begin{array}{l}\text { Capital investment in environmental } \\
\text { protection }\end{array}$ \\
\hline 2013 & 6719,8 & 6038783 \\
\hline 2014 & 5186,6 & 7959853,9 \\
\hline 2015 & 4521,3 & 7675597 \\
\hline 2016 & 3078,1 & 13390477,3 \\
\hline 2017 & 2923,8 & 11025535,2 \\
\hline 2018 & 3053,9 & 10074279,3 \\
\hline
\end{tabular}

Source: compiled by the author based on [9]

This shows that the relationship between variables and dependencies is high. That is, the relationship between emissions of harmful substances, namely carbon dioxide, and the flow of capital investment in environmental protection is clearly expressed by the results of correlation and regression analysis.

Table 2 - Relationship between emissions of harmful substances and the volume of capital investment in environmental protection in Ukraine

\begin{tabular}{|l|c|}
\hline \multicolumn{1}{|c|}{ Regression statistics } & Indicator \\
\hline Multiple R & 0,876323094 \\
\hline R-square & 0,767942166 \\
\hline Normal R-square & 0,709927707 \\
\hline Standard error & 820,8233566 \\
\hline Surveillance & 6 \\
\hline
\end{tabular}

Source: compiled by the author based on [9]

The need to invest in ecology and environmental protection emphasizes the importance of a circular economy in today's world. A closed cycle, reuse of resources and their processing can reduce the industrial and consumer burden to the planet.

The circular economy is increasingly perceived as an important concept with which to achieve economic and environmental goals. However, more time is needed for politics, business, science and society to embrace and feel the potential of the transition to the new model. Initial calculations indicate that the introduction of a circular economy has significant positive potential. For Europe, this potential is to reduce emissions of pollutants and material-intensive industries by about $50 \%$ and above. An important component of the circular economy is the processing and reuse of materials in various spheres of life. The European Union is now actively fighting plastic. By 2029, EU countries must ensure a $90 \%$ collection rate for used plastic bottles. By 2025, plastic bottles must consist of at least 25 percent recycled plastic, in 2030 - at least 30 percent [10].

\section{Conclusions}

Of course, there are barriers and obstacles to the transition from a traditional linear to a circular economy. They occur at virtually all levels and are often interdependent and include not only fiscal barriers but also operational and technical issues at the corporate level. In Germany, for example, there is a goal of benefiting from the circular economy as a way of aligning environmental goals with greater productivity, innovation, competitiveness and employment. The main policy instruments that provide targeted support for the transition to a circular economy are already in place, an increasing number of initiatives and stakeholders are addressing this issue, and there is an expanded public funding strategy. Germany must demonstrate that resource savings and a closed cycle of economic growth are a competitive and significant advantage over uncontrolled resource consumption. However, society as a whole still lacks a common vision of the transition to a circular economy, which describes the main motivation for systemic change, connects it with existing political goals in other policy areas. We must at least begin with the development of a narrative that 
emphasizes the comprehensive relevance of the circular economy. With this document it will be easier to convey to the world the benefits of a circular economy. Also make various suggestions on how this concept can be systematically developed and implemented among all relevant stakeholders.
Germany's experience in implementing government programs for the development of the circular economy, providing grants for joint projects, creating a new concept of production and processing, modernization of environmentally friendly packaging, stimulating the development of consortia (small and medium enterprises) is important for Ukraine.

\section{References}

1. R.C. Brears (2018). Germany’s 2022 Circular Economy. URL: https://medium.com/mark-and-focus/germanys-2022circular-economy-214b7ad8470f[in Ukrainian].

2. Th. Weber, M. Stuchtey (2019). Pathways towards a German Circular Economy. URL: https: //www.acatech.de/wp content / uploads / 2019/07 / Circular_Economy_EN.pdf[in Ukrainian].

3. M. Nelles, J. Grünes, G. Morscheck (2016). Waste Management in Germany - Development to a Sustainable Circular Economy? URL: https://www.sciencedirect.com/science/article/pii/S1878029616300901

4. J. Fedorchuk, D. Servetnik (2019). Circular economy. Organizational and legal aspects. URL: https://www.businesslaw.org.ua/circle-economic-t/[in Ukrainian].

5. What are the disadvantages of the current linear economy? URL: https://kenniskaarten.hetgroenebrein.nl/en/knowledge-map-circular-economy/ce-disadvantages-linear-economy/[in Ukrainian].

6. Chinese Commerce Minister Chen Deming. URL: https://www.c-span.org/video/?304835-1/chinese-commerceminister-chen-deming\&event $=304835 \&$ playEvent

7. Electric cars provoked a struggle for metals. URL: https://www.vedomosti.ru/business/articles/2017/10/25/739339elektromobili-borbu-metalli[in Ukrainian].

8. Why did Ukraine take 18th place in the 2019 climate change ranking? URL: https://ecoaction.org.ua/chomu_18_misce.html

9. State Statistics Service of Ukraine. URL: http://www.ukrstat.gov.ua/

10. Europe has finally banned plastic utensils. URL: https://www.ens.az/en/evropa-okonchatelno-zapretila-plastikovuyuposudu[in Ukrainian]. 